\title{
The performance assessment of Khouribga waste water treatment plant: diagnostics, gaps and operating guide
}

\author{
Ghalia RAJHY*, Driss KHOMSI1 \\ ${ }^{1}$ Mohammadia School of Engineering, University Mohammed V, BP 765, Rabat, Morocco
}

\begin{abstract}
This article presents an evaluation's results about performances of Khouribga's Wastewater Treatment plant. In general, the purpose of proposed model for the performances evaluation being is to check the quality and quantity of the system goals compared to the design data and the legislation. The quality goals being not verified in our case, the plant operation's diagnosis is deployed to detect the different meanings impacts caused by some points of controls and to raise the causes of these anomalies. Through a feedback experience, some corrective and preventive actions will be proposed to treat the dysfunction. A follow up of the evolution of the performance is proved to be necessary and adds up as an experience feedback in a Moroccan context.
\end{abstract}

\section{Introduction}

In Morocco, the volume of rejected waste water was estimated at $750 \mathrm{Mm}^{3} /$ year in $2015[1]$. In contrary of the developed countries, more than $50 \%$ of these rejects are released in the nature [1] causing then nuisances in the environmental, sanitary and esthetical order. Morocco faces now 2 challenges : in one hand limiting the direct rejects of waste water in the receiving places by ensuring their treatment and their sanitation, and in a second hand looking for a way to value this water to profit from it specially as an hydric resource. The WWTPs represent an important field as for the valorisation of the material ( reuse the treated water, the sludge production ) and energetic ( the heat production, electricity), otherwise, only $20 \%$ of the waster water is reused. The actual inventory realized of the existing treatment plant in Morocco, shows at what point these unities, especially the ones handled by the cities, know some difficulties to accomplish their work and are sometimes abandoned for many reasons. It it necessary to reassess the performance of the current stations and start using this model as a better conception. The performance analysis of the plant's choice was Khouribga's WWTP. It is consisting of biological treatment with activated sludge system and includes the tertiary treatment in order to reuse the treated waste water for the phosphate wash. A qualitative performance analysis leaded us to diagnose these plant and raise the differences compared to the requirements, the international standards and the one defined in the litterature. Subsequently, functional solutions are proposed for energy, environmental and financial optimization of operations. Since publications of case studies in Morocco are rare, this study will contribute to adding documentation in a Moroccan context.

\section{METHODOLOGY:}

The methodology suggested to evaluate the performance of a wastewater plant is presented in figure 1 and enlisted below.

The case study worked on this project for the application of that methodology is the wastewater treatment plant Khouribga (WWTPK).

WWTPK is an existent plant renovated to treat urban wastewater with the activated sludge system for average load with two parallel liquid lines; Each line consists of a pre-treatment (screens, grit and grease chamber), a secondary treatment of activated sludge system and tertiary treatment using mechanical treatment and followed by microfiltration and disinfection using the $\mathrm{NaClO}$.

The sludge treatment consists of thickening, digestion and sludge drying. The present system products biogaz by anaerobic digestion of the sludge and is used to generate electrical energy and heat. A co-generator and heater are installed in the present plant.

The plant was constructed in 2013 with a design capacity up to $15700 \mathrm{~m} 3 / \mathrm{d}$ in 2020 (average load). The effluent at the end of the WWTP disposal standards fixed by the exploitant are $10 \mathrm{mg} / \mathrm{L}$ as target of the concentration of total suspended solids; $10 \mathrm{mg} / \mathrm{L}$ for biological oxygen Demand $\left(\mathrm{BOD}_{5}\right) ; \quad 50 \mathrm{mg} / \mathrm{L}$ for chemical oxygen demand (DOC) and 1000 units / $100 \mathrm{~mL}$ as limit of the faecal coliforms.

The wastewater treated is reused for cleaning the crude phosphate in a production plant. That explains why the qualitative standards are higher than the ones fixed by the Moroccan legislation and destined to be rejected in the river.

Fig. 1.Description of the methodology defined for the performance evaluation of a wastewater treatment plant

Rajhy Ghalia: rajhy.ghalia@.gmail.com 


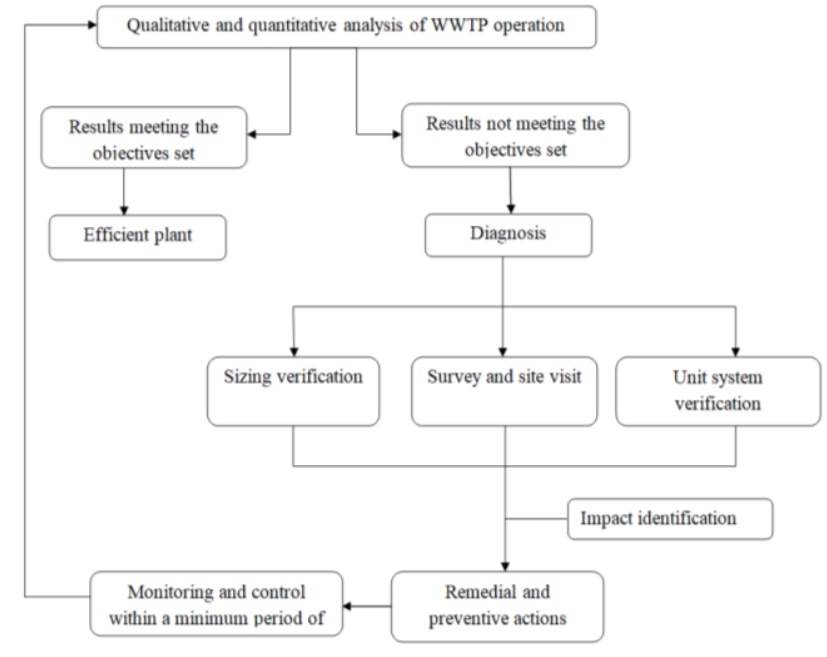

2.1 Field Measurements

As a first step towards performance assessment of Khouribga case study, the field measurements from March 2015 to March 2016 were gathered to conduct the quality and quantity data about the influent and effluent of WWTP. Samples were collected according to the methodology described in the exploitation guide and analysed in the laboratory.

The parameters aimed are the $\mathrm{BOD}_{5}, \mathrm{DOC}$ and TTS. The quality of the water is measured at two states : at the the second and the tertiary treatment. These particular datas are the base to evaluate the qualitative objectives of the WWTP fixed by the organism in the design and defined in table 1.

Table 1. Quality objectives defined in the specifications

\begin{tabular}{|c|c|c|c|}
\hline $\begin{array}{c}\text { Quality } \\
\text { objectives }\end{array}$ & BOD $_{5}$ & DOC & TTS \\
\hline $\begin{array}{c}\text { Primary } \\
\text { treatment }\end{array}$ & Not defined & Not defined & Not defined \\
\hline $\begin{array}{c}\text { Secondary } \\
\text { treatment }\end{array}$ & $25 \mathrm{mg} / \mathrm{L}$ & $30 \mathrm{mg} / \mathrm{L}$ & $120 \mathrm{mg} / \mathrm{L}$ \\
\hline $\begin{array}{c}\text { Tertiary } \\
\text { treatment }\end{array}$ & $10 \mathrm{mg} / \mathrm{L}$ & $10 \mathrm{mg} / \mathrm{L}$ & $50 \mathrm{mg} / \mathrm{L}$ \\
\hline
\end{tabular}

This step consists in the analysis of the statistics of the $\mathrm{BOD}_{5}$, DOC and TTS measurements at the entry of the WWTPs, after the biological treatment and at the end of the tertiary treatment from March 2015 to March 2016.

It is also a question of measuring the number and occurrence of detected discrepancies and verifying their admissibility according to European legislation.

\subsection{Qualitative and quantitative analysis of the WWTP K}

The first step in the logigram consists of recording the differences in compliance of the different control points defined during this evaluation process (3). These system performance indicators are first of all the nonconformances of the average data compared to the Design data, in order to check the achievement of quality objectives and to note if the station is not overloaded before the horizon defined.

This is followed by the verification of the noncompliance of the discharges in the environment with respect to the thresholds set in Annex II of the amended European Ministerial Decree of 31/01/2008.

Finally, the compliance of the sludge and gas sector verified by the dryness of sludge eligible for the landfill and $\mathrm{CO} 2$ emissions through the combustion of biogas in the flare.

\subsection{Sizing control and verification}

In Figure 1, the analysis also consists of checking the sizing of the various structures of the plant against the rules of good practice suggested in the different French and Anglo-Saxon literatures. This verification is necessary throughout the process and makes it possible to highlight the criteria that do not meet the prediction during the design.

Table 2 summarizes the parameters aimed to be verified, their respective equations as well as the typical value ranges for each system unit or process.

This inspection shall include an assessment of the WWTP sizing. The evaluation will be applied on the actual dimensions and loads of different systems of the plant. Then the results will be compared with the conception requirements and criterias defined in table 2 .

\subsection{Questionnaire}

The questionnaire is designed to complete the diagnosis with an expert operator's view of the operation and daily hazards that are in situ. As a complement to fieldwork experience, it is a complement to the theoretical analysis of design verification.

The questionnaire is divided in 3 parts :

1. Questions about the fonctional abnormalities that exists: (i) installations's changes and failures (ii) smell's problem and leaks (iii) nonoperational files;

2. Questions about the exploitation (i) pumping system's existence (ii) ) the solid and liquid output elements's destination of each structure (iii) The sampling method adopted and measurements's periodicity;

3. The adopted performance criteria ( internationals and initiative standars of the organism).

The questionnaire was communicated in situ during the WWTP PLANT visits.

The results and debates are presented in the following section where the results of the methodology defined above will be listed. 
Table 2. Design criterias

\begin{tabular}{|c|c|c|}
\hline $\begin{array}{l}\text { Treatment } \\
\text { unit }\end{array}$ & $\begin{array}{l}\text { Verification } \\
\text { criteria }\end{array}$ & $\begin{array}{l}\text { Typical value } \\
\text { ranges }\end{array}$ \\
\hline Screening & Head loss & 76 à 152 mm [2] \\
\hline $\begin{array}{l}\text { Grit and } \\
\text { grease } \\
\text { Removal }\end{array}$ & $\begin{array}{l}\text { Flow velocity } \\
\text { Hydraulic retention } \\
\text { time (HRT) }\end{array}$ & $\begin{array}{l}5 \text { à } 15 \mathrm{~m} / \mathrm{h} \\
15 \text { à } 20 \mathrm{~min}\end{array}$ \\
\hline $\begin{array}{l}\text { Primary } \\
\text { sedimentation }\end{array}$ & $\begin{array}{l}\text { HRT } \\
\text { Overflow rate } \\
\text { Weir loading }\end{array}$ & $\begin{array}{l}90 \text { à } 150 \mathrm{~min}[2] \\
30 \text { à } 50 \mathrm{~m}^{3} / \mathrm{m}^{2} / \mathrm{d} \\
125 \text { à } 190 \mathrm{~m}^{3} / \mathrm{m} / \mathrm{d}\end{array}$ \\
\hline $\begin{array}{l}\text { Secondary } \\
\text { treatment - } \\
\text { Activated } \\
\text { Sludge for } \\
\text { average load }\end{array}$ & $\begin{array}{l}\text { Organic load } \\
\text { Volumetric loading } \\
\text { Hydraulic retention } \\
\text { time } \\
\text { Solid retention time } \\
\text { Mass of cells } \\
\text { (biomass ) } \\
\text { Efficiency }\end{array}$ & $\begin{array}{c}0,25 \text { à } 0,5 \mathrm{~kg} \mathrm{BOD}{ }_{5} \\
/ \mathrm{kg} \mathrm{SSLM} / \mathrm{j} \\
0,8 \text { à } 1 \mathrm{~kg} \mathrm{DBO} 5 \\
/ \mathrm{m} 3 / \mathrm{j} \\
4 \text { à } 10 \mathrm{~h} \\
3 \text { à } 7 \mathrm{j} \\
3 \text { to } 4 \mathrm{~g} / \mathrm{L} \\
80 \text { to } 90 \text { percent }\end{array}$ \\
\hline Clarifier & $\begin{array}{l}\text { HRT } \\
\text { Overflow rate }\end{array}$ & $\begin{array}{c}1.5 \text { à } 3 \mathrm{~h} \\
16 \text { to } 28 \mathrm{~m}^{3} /\left(\mathrm{m}^{2} . \mathrm{d}\right) \\
{[2]}\end{array}$ \\
\hline Thickening & $\begin{array}{l}\text { Retention time } \\
\text { Solids loading }\end{array}$ & $\begin{array}{c}1 \text { à } 3 \mathrm{~d} \\
30 \text { à } 60 \mathrm{~kg} \mathrm{MS} / \mathrm{m}^{2} / \mathrm{d}\end{array}$ \\
\hline Digestion & $\begin{array}{l}\text { Solid Retention } \\
\text { Time (SRT) } \\
\text { Charge volumique }\end{array}$ & $\begin{array}{c}10 \text { à } 14 \mathrm{~d} \\
3 \mathrm{à} 4 \mathrm{~kg} \mathrm{MV} / \mathrm{m}^{3} / \mathrm{d}\end{array}$ \\
\hline
\end{tabular}

\section{Results and discussions}

\subsection{Qualitative and quantitative performance evaluation of the WWTP Khouribga}

The current plant was sized for the 2020 horizon. The qualitative and quantitative analysis was carried out from daily sampling, at 3 different points; the first one is the entrance of the plant, second is the exit of the clarifier and third in the tertiary treatment. These different sampling are measured in the laboratory to extract the required qualitative values. The comparison of these measured values with Design nominal values is detailed in Table 3 with the calculation of the occurrence of the exceedance.
Table 3. Analysis of the conformities of the treatment units.

\begin{tabular}{|c|c|c|c|}
\hline $\begin{array}{c}\text { WWTP } \\
\text { Khouribga }\end{array}$ & $\begin{array}{c}\text { Design } \\
\text { Data fixed } \\
\text { for } 2020\end{array}$ & $\begin{array}{c}\text { Average } \\
\text { loads } \\
\text { during the } \\
\text { study } \\
\text { period } \\
\end{array}$ & $\begin{array}{c}\text { Ratio of } \\
\text { Exceedances } \\
\text { compared to } \\
\text { design data } \\
\text { of } 2020(\%)\end{array}$ \\
\hline \multicolumn{4}{|c|}{ Plant entrance } \\
\hline $\begin{array}{c}\text { Flow rate } \\
\left(\mathrm{m}^{3} / \mathrm{d}\right)\end{array}$ & 55200 & 13362 & 0 \\
\hline $\mathrm{BOD}_{5}(\mathrm{~kg} / \mathrm{d})$ & 6900 & 4905 & 11,4 \\
\hline COD $(\mathrm{kg} / \mathrm{d})$ & 13800 & 8164 & 3,6 \\
\hline TSS $(\mathrm{kg} / \mathrm{d})$ & 8300 & 3367 & 1,4 \\
\hline \multicolumn{4}{|c|}{ Exit of the aerobic reactor ( Activated sludge system) } \\
\hline $\mathrm{BOD}_{5}(\mathrm{mg} / \mathrm{L})$ & 25 & 19 & 17,1 \\
\hline $\mathrm{COD}(\mathrm{mg} / \mathrm{L})$ & 120 & 78 & 0,9 \\
\hline $\mathrm{TSS}(\mathrm{mg} / \mathrm{L})$ & 30 & 21 & 6,8 \\
\hline \multicolumn{4}{|c|}{ Exit of the plant (Treated water) } \\
\hline $\mathrm{BOD}_{5}(\mathrm{mg} / \mathrm{L})$ & 10 & 19 & 84,4 \\
\hline $\mathrm{COD}(\mathrm{mg} / \mathrm{L})$ & 50 & 77 & 99,1 \\
\hline TSS (mg/L) & 10 & 20 & 96,7 \\
\hline
\end{tabular}

Our analysis of nonconformities will be done on rates, in order to facilitate the future evaluation of the performances between different plants.

$11,4 \%$ of the organic matter samples recorded at the entrance of the WWTP exceeds the nominal capacities planned for 2020. This overload also affects the quality objectives of the biological treatment where $17 \%$ of the samples do not respect the quality objectives in BOD. Tertiary treatment is considered ineffective where the reduction of pollution has not reached its objective. Low efficiency is then reported.

The pollution at the exit of the station does not respect the objectives of Design but respects globally the thresholds fixed by the Moroccan legislation which is a maximal rejection of $\mathrm{BOD}_{5}$ and TSS of $30 \mathrm{mg} / \mathrm{L}$.

For the legislative approach, a maximum number of noncompliant samples are set in Table 8 of Annex 3 of the « Arrêté du 21 juillet 2015 relatif aux systèmes d'assainissement collectif et aux installations d'assainissement non collectif, à l'exception des installations d'assainissement non collectif recevant une charge brute de pollution organique inférieure ou égale à $1,2 \mathrm{~kg} / \mathrm{j}$ de DBO5 » and are respectivly $11,4,7,3$ and $7,2 \%$ [3] for BOD , COD and TSS. These tresholds are compared to the values of the samples at the exit of the biological treatment. The measurement of BOD of $17 \%$ of the samples is overall the threshold defined by the organism. A anomaly of the BOD removal is detected and is due to the important organic load in the waste water compared to what was predicted in the specifications.

Following the quantitative analysis of the discharges to the receiving environment, the plant recorded during the measurement period a quantity of discharge of 100621,6 $\mathrm{kg}$ of biodegradable pollutant load that exceeds the release threshold of $43000 \mathrm{~kg}$ year [4]. These discharges were done in order to lower the organic load. The 
efficiency of the biological reactor for average low is defined, The reduction of loads at the entrance will improve the quality of water at the exit of the activated sludge system.

The quality of the sludge at the outlet must have a dryness greater than $20 \%$ fixed by the project. However, $75 \%$ of the measurements at the outlet of the band filter are non-compliant.

The valorization of biogas is non-consistant: $2.8 \mathrm{GWh}$ are lost in 2015. This generated an energy over-invoicing of $1.62 \mathrm{Mdhs}$ for electricity consumption and an emission of 620,000 tonnes of $\mathrm{CO} 2$ due to the combustion of non-upgraded biogas.

\subsection{Diagnosis of the treatment system}

\subsubsection{Sizing verification}

Verification of sizing is a step in defining the assessment results causes. These results are statistically expressed to facilitate analysis and comparison. For the WWTPK, 5 design criteria are checked among 22 , or $22 \%$ of the criteria are verified.

\subsubsection{The questionnaire results}

Through the questionnaire, several points and modifications of the configuration were noted. First, the operator ordered the installation of a rotating drum downstream of the thickener since the concentration of the sludge at the outlet is $40 \mathrm{~g} / \mathrm{L}$ while it is recommended a concentration of $45 \mathrm{~g} / \mathrm{L}$ at the inlet of the digester. To solve the problem of exceeding the quality objectives in reducing the pollutant load at the outlet of the BA system, the 2nd aeration tank has been transformed into a "stabilization contact" system.

As functional anomalies detected, the presence of stable foams on the surface of the aeration reactors reflects a phenomenon of scepticism. Also, the clarifier has a problem with floating algae, grease and dead mud.

The breakdowns detected during our site visit are :

- The biological basin aerator 2 for stabilization and its dissolved oxygen sensor; to remedy to this situation of lacking of the oxygen contents of the liquor in this basin, the operator uses the aeration command similar to Pond $\mathrm{N}^{\circ}$;

- A shutdown of the boiler in March 2016 resulted in unstabilized sludge and low biogas production. An expenditure of $170000.00 \mathrm{DHs}$ was charged for heating the digester.

- The co-generator.

With regard to the exploitation, there is no analysis of ammoniacal nitrogen and $\mathrm{pH}$ of the sludge of the digester.
For an overall evaluation of the plant, we summarize the results of the indicators obtained to evaluate the different control points. Table 4 includes the results of the diagnosis.

Table 4. Summary of the Degree of Evaluation of the Performance Criteria

\begin{tabular}{|l|l|l|}
\hline \multicolumn{2}{|l|}{ Performance Criteria } & $\begin{array}{l}\text { Degree } \\
\text { Evaluation }\end{array}$ \\
\hline Qualitative and quantitative analysis results \\
\hline $\begin{array}{l}\text { Quality of treated } \\
\text { water ( outlet of the } \\
\text { plant ) }\end{array}$ & TSS & Acceptable \\
\cline { 2 - 3 } & $\mathrm{BOD}_{5}$ & Acceptable \\
\cline { 2 - 3 } Energy consumption & COD & Acceptable \\
\cline { 2 - 3 } & Fuectricity & Not acceptable \\
\hline \multirow{2}{*}{$\begin{array}{l}\text { Atmospheric } \\
\text { emissions }\end{array}$} & $\begin{array}{l}\text { carbon } \\
\text { dioxide }\end{array}$ & Acceptable \\
\hline \multirow{2}{*}{ Water discharges } & TSS & Acceptable \\
\cline { 2 - 3 } & BOD $_{5}$ & Not acceptable \\
\cline { 2 - 3 } & COD $^{2}$ & Acceptable \\
\hline Project and exploitation evaluation \\
\hline \multirow{2}{*}{ Verification of the sizing } & Not verified \\
\hline \multirow{2}{*}{ Site statement } & Not acceptable \\
\hline
\end{tabular}

\subsection{Identification of causes and proposal of corrective and preventive solutions}

After analysis and diagnosis, the various problems with significant impacts related to the station are first The operation and arrangement of the lines of the plant; Presence of floats, weak dryness of sludge; Stable foams; direct discharge of raw water and treated water in the receiving environment.

These phenomena are at the origin of the disruption of the station's operation and performance. The challenge now is to propose appropriate corrective or preventive solutions.

\subsubsection{Layout of station queues}

In the previous diagnosis, the design criteria for biological treatment are not verified because of the very large volume of biological basins but also because of insufficient control and adaptation of recirculation at the inlet.

For input data for 2020, only one water line of the activated sludge treatment must be operating. This configuration validates the design criteria.

By 2030, the 2nd row will have to be commissioned, adjusting the TRS to lower temperatures. 
By setting a biomass of $3 \mathrm{~g} \mathrm{SSLM} / \mathrm{L}$ at $12^{\circ} \mathrm{C}$, the design criteria are verified.

For a lower biomass, our sludge recycling rate will be lower, at $70 \%$ instead of $90 \%$ by 2030 .

As these scenarios are proposed, they must be checked and controlled. Brdjanovic used an application combining the Activated Sludge Model N³ (Gujer et al. 1999) and the Anaerobic Digestion Model N¹ (Bastone et al. 2002) to optimize the performance of a wastewater treatment plant in India[5]. This application allowed him to predict the different scenarios and configurations necessary to maintain the quality of the treatment.

\subsubsection{Floats}

This floating problem is due to incomplete denitrification and sludge fermentation as mentioned above.

To avoid the floaters associated with wild denitrification, it is necessary to modify the residence time of the sludge in the clarifier. This time should be less than 2 hours according to the recommendation of the FNDAE[6] [7] . This will also allow us to limit sludge fermentation while regulating the oxygen requirement. In the case of wild nitrification, a two-hour shutdown of the aerators is essential: This action creates an anaerobic zone, thus promoting denitrification.

\subsubsection{Low sludge dryness}

By taking over the existing drying beds from the municipality that operated the WWTP, the sludge dryness will be rectified and in compliance with the regulations for controlled landfills. The residence time calculated for 40 drying beds $34 \mathrm{~m}$ long and $5 \mathrm{~m}$ wide is 17 days until 2020.

\subsubsection{Stable foams}

Stable foams are defined as a mixture of three components: sludge particles, air bubbles, and filamentous microorganisms. These latter develop under conditions of high fatty acid concentrations with limited oxygenation[8]; The main causes of this fatty acid concentration are: septicity events ( a prolonged presence in structures upstream of the aeration basin), sludge fermentation (very important age of sludge), or poor oil separator functioning.To prevent this bacterial development, several recommendations are made: Avoid sepsis phenomena upstream of biological treatment; Avoid the reinjection of floats into the aeration tank; Prevent the return of sludge that develops in the anaerobic zone.

\section{Conclusion}

In general, the performance evaluation procedure made it possible to verify the different processing units in terms of performance and compliance with contractual quality and quantity objectives. The flowchart made it possible to detect the different points that are related to design anomalies, both functional and qualitative.

The Khouribga Wastewater Treatment Plant was a valuable model because it is a mature plant whose sampling data has allowed us to have reliable results.

At present, the various treatment processes are not used properly; several losses in materials (discharges of treated water), energy (the absence of cogeneration) and financial (energy bill) are highlighted.

The organization responsible for the station must think about further control by using mathematical modelling software to predict the station's operation and optimize treatment for better efficiency. For that, the Activated sludge model $\mathrm{N}^{\circ} 1$ ( ASM1) is the most accurate for this situation : Constant temperature and $\mathrm{pH}$; moreover the non-appliance of the azote and phosphorus removal [9]. Followed by the calibration step using the protocol suggested by Vanrolleghem PA et al. In 2003 [10]. This processus in modelling will help the user to have a good description of the Carbone removal, to prevent the abnormality behaviours of the WWTP and optimize scenarios in a later phase[11] .

\section{References}

1. Ministère de l'énergie, des mines et de l'environnement, Département de l'environnement, Programme national de l'assainissement liquide (2015) [http://www.environnement.gov.ma/fr/eau?id=425]

2. Tchobanoglous, G., Burton, F. L., and Stensel, H. D., Metcalf \& Eddy wastewater Engineering (2003)

3. Arrêté du 21 juillet 2015 relatif aux systèmes d'assainissement collectif et aux installations d'assainissement non collectif, à l'exception des installations d'assainissement non collectif recevant une charge brute de pollution organique inférieure ou égale à $1,2 \mathrm{~kg} / \mathrm{j}$ de $\mathrm{DBO}_{5}$. Version consolidée au 01 Janvier 2016

4. Arrêté du 31/01/08 relatif au registre et à la déclaration annuelle des émissions et des transferts de polluants et des déchets

5. D. Brdjnovic, M.Mithaiwala, M.S. Moussa, G. Amy and M.C.M van Loosdrecht, Use of modelling for optimization and upgrade of a tropical wastewater treatment plant in a developing country (2007)

6. L'épaississement des boues : les règles de bonne gestion. Canler J.-.P., Cauchi A., Duchène Ph., Fernandes P., Larigauderie A., Leboucher G., Pujol R., Cemagref Lyon QELY, Générale des eaux, Paris, Cemagref Antony QEAN, Anjou Recherche, SAUR Tours, Lyonnaise des eaux, Paris, TSM, $\mathbf{n}^{\circ} \mathbf{4}$, (2002)

7. La clarification : approche dimensionnelle basée sur le couple aération-clarification. Fondements et évolutions, Canler J.-.P., Perret J.-M., 83e congrès de l'ASTEE, Aix-les Bains, ( 2004)

8. PH. Duchene-R.Pujol, M. Payraudeau, N. Hyvrard, M.P Humbey, M. Capellier-A.Larigauderie, L. 
Barillot-R.Turgis et C. Trousselle, Guide de lutte contre les mousses biologiques stables (1993)

9. Henze, M., Grady, C. P. L. Jr., Gujer, W., Marais, G. v. R. \& Matsuo, T. Activated Sludge Model No. 1. IAWPRC Scientific and Technical Reports No. 1. London, UK (1987)

10. Vanrolleghem PA, Insel G, Petersen B, Sin G, De Pauw D, Nopens I, Weijres S, Gernaey K, A comprehensive model calibration procedure for activated sludge models (2003)

11. Britta Petersen, Krist Gernaey, Mogens Henze and Peter A.Vanrolleghem, Evaluation of an ASM1 model calibration procedure on a municipalindustrial wastewater treatment plant (2002) 